TABLE II-Details of patients who died in azathioprine group (azathioprine plus prednisone) and control group (prednisone alone)

\begin{tabular}{|c|c|c|c|}
\hline $\begin{array}{c}\text { Age at } \\
\text { death } \\
\text { (years) }\end{array}$ & Treatment at death & Cause of death & $\begin{array}{c}\text { Time from } \\
\text { onset }\end{array}$ \\
\hline \multicolumn{4}{|c|}{ Azathioprine group } \\
\hline $\begin{array}{l}65 \\
85\end{array}$ & $\begin{array}{l}\text { Nil } \\
\text { Azathioprine }+ \\
\text { prednisone }\end{array}$ & $\begin{array}{l}\text { Cerebrovascular accident } \\
\text { Cerebrovascular accident }\end{array}$ & $\begin{array}{l}3 \text { years } \\
1 \text { month }\end{array}$ \\
\hline 85 & $\begin{array}{c}\text { Azathioprine }+ \\
\text { prednisone }\end{array}$ & $\begin{array}{l}\text { Congestive cardiac } \\
\text { failure }\end{array}$ & 10 months \\
\hline \multicolumn{4}{|c|}{ Control group } \\
\hline $\begin{array}{l}76 \\
76\end{array}$ & $\begin{array}{l}\text { Prednisone } 20 \mathrm{mg} / \text { day } \\
\text { Prednisone } 15 \mathrm{mg} / \text { day }\end{array}$ & $\begin{array}{l}\text { Bronchopneumonia } \\
\text { Massive haemorrhage } \\
\text { from peptic ulcer }\end{array}$ & $\begin{array}{l}1 \text { year } \\
7 \text { months }\end{array}$ \\
\hline $\begin{array}{l}77 \\
80\end{array}$ & $\begin{array}{l}\text { Prednisone } 20 \mathrm{mg} / \text { day } \\
\text { Nil }\end{array}$ & $\begin{array}{l}\text { Mesenteric thrombosis } \\
\text { Cerebrovascular accident }\end{array}$ & $\begin{array}{l}2 \text { months } \\
6 \text { months }\end{array}$ \\
\hline
\end{tabular}

and Greaves ${ }^{2}$ reported that two out of 12 patients in a prospective but uncontrolled trial died of cancer within two years after starting azathioprine treatment. They suggested that the risk of disseminated malignancy after suppression of immunosurveillance may be greater in patients with pemphigoid than in others because of the suspicion that the disease may occasionally be secondary to occult or overt malignancy. ${ }^{56}$ Even if there is no causal relation between cancer and pemphigoid, few would dispute that occult malignancy is more likely to be present in elderly patients than in those from younger age groups, and patients with pemphigoid, being elderly, might be particularly at risk from immunosuppressive drugs. Our controlled study, in which patients were carefully followed for three years, showed no evidence of this, and azathioprine produced a significant decrease in steroid requirements with minimal side effects.

A recent uncontrolled study, in which 14 patients with mild pemphigoid were treated with prednisone alone and 15 more severe cases received azathioprine $1.5 \mathrm{mg} / \mathrm{kg}$ plus prednisone, showed that even a low dose of azathioprine exerts a steroidsparing effect with minimal toxicity. ${ }^{7}$

We conclude that azathioprine plus prednisone is superior to prednisone alone in the treatment of pemphigoid, and future trials should use this combination as the standard for comparison.

\section{References}

1 Friedmann, E A, et al, Transplantation, 1973, 15, 619.

2 Burton, J L, and Greaves, M W, British fournal of Dermatology, 1974, 91, 103

${ }^{3}$ Greaves, M W, et al, British Medical fournal, 1971, 1, 144

4 Van Dijk, T J A, and Van Velde, J L, Dermatologica, 1973, 147, 179.

5 Parsons, R L, and Savin, J A, British fournal of Cancer, 1968, 22, 669.

6 Saikia, N K, Mackie, R M, and McQueen, A, British fournal of Dermatology, 1973, 88, 331 .

${ }^{7}$ Ahmed, A R, Maize, J C, and Provost, T T, Archives of Dermatology, 1977, 113, 1043.

(Accepted 14 September 1978)

\title{
Relation of high-density lipoprotein cholesterol concentration to type of diabetes and its control
}

\author{
A L KENNEDY, T R J LAPPIN, T D LAVERY, D R HADDEN, J A WEAVER, \\ D A D MONTGOMERY
}

British Medical fournal, 1978, 2, 1191-1194

\section{Introduction}

Serum cholesterol may be partitioned into high- and low-density lipoprotein fractions (HDL and LDL cholesterol respectively). Results of previous lipid studies have generally emphasised that serum cholesterol and low-density lipoproteins have a positive relation with coronary heart disease. Recently an inverse relation has been found between serum HDL cholesterol and coronary heart disease, ${ }^{1}$ and a low concentration of serum HDL cholesterol has been suggested as the major lipid risk factor. ${ }^{2}{ }^{3}$ In diabetes mellitus low serum HDL cholesterol concentrations have been associated with the increased incidence of coronary heart disease in women. ${ }^{4}$ It has been claimed that poorly controlled diabetics have significantly lower serum HDL cholesterol concentrations than those with good blood sugar control, ${ }^{5}$ and that patients receiving sulphonylurea treatment have lower concentrations than those treated with insulin or with dietary measures alone. ${ }^{6}$

We have analysed concentrations of serum cholesterol and its HDL fraction in relation to the type of diabetes-that is, juvenile-onset or maturity-onset. We have also studied the glycosylated $\mathrm{Hb} \mathrm{A}_{1 \mathrm{C}}$ concentration, which has been regarded as an integrated index of blood sugar control over the previous weeks. ${ }^{78}$

\section{Subjects and methods}

We studied 192 diabetic patients attending the hospital diabetes clinic. Ninety-four ( 45 male and 49 female) patients had juvenileonset diabetes (age less than 40 years at time of diagnosis and needing

\footnotetext{
Royal Victoria Hospital, Belfast BT12 6BA

A L KENNEDY, MRCP, senior registrar

T D LAVERY, FIMLS, chief medical laboratory scientific officer

D R HADDEN, FRCPE, physician

D A D MONTGOMERY, MBE, FRCP, physician-in-charge, Sir George E Clark Metabolic Unit
} 
insulin treatment) and 98 (61 men and 37 women) had maturity-onset diabetes (age over 40 at time of diagnosis; treated by diet or oral hypoglycaemic agents, or both). None of the diabetic patients was ketotic when studied. The controls comprised 177 non-diabetic subjects ( 91 male, 86 female), who were staff volunteers, blood donors, or orthopaedic patients.

We took 14-hour overnight fasting and two-hour postprandial venous blood samples in the initial 40 subjects to determine whether cholesterol and HDL cholesterol concentrations in fasting and nonfasting samples were comparable. All other blood samples were taken at random, mid-morning or mid-afternoon. A simultaneous blood sample was taken in addition in 89 diabetics for measurement of $\mathrm{Hb} \mathrm{A}_{1 \mathrm{C}}$. Sixty of the patients with maturity-onset diabetes were taking part in an established prospective study of intensive dietary management of maturity-onset diabetes, ${ }^{9}$ and data on fasting plasma insulin concentrations, triglyceride concentrations, and percentage ideal body weight were also available.

Serum cholesterol and triglyceride concentrations were measured by the standard Technicon SMAC method. Serum HDL cholesterol concentrations were measured by the CHOD-PAP technique (Boehringer), incorporating EDTA to prevent interference from manganese, ${ }^{10}$ low-density and very-low-density lipoproteins being first precipitated off with manganese chloride and heparin. Haemoglobin $\mathbf{A}_{1 \mathrm{C}}$ was measured by the column chromatography method of Trivelli $e t a l,{ }^{11}$ and plasma insulin by radioimmunoassay.

\section{Results}

Figure 1 shows the close relation $(r=0.91)$ between fasting and non-fasting HDL cholesterol concentrations in the first 40 subjects. Subsequent results refer to non-fasting concentrations only. All results are given as means $t$ SE of mean.

The mean HDL cholesterol concentration in the 106 male diabetics was $1.39 \pm 0.03 \mathrm{mmol} / 1(53.8 \pm 1.2 \mathrm{mg} / 100 \mathrm{ml})$ compared with $1.40 \pm 0.03 \mathrm{mmol} / 1(54.2 \pm 1.2 \mathrm{mg} / 100 \mathrm{ml})$ in the 91 male controls. The difference was not significant (Student's $t$ test for unpaired data). The mean concentrations in the 86 female diabetics and 86 female controls were respectively $1.53 \pm 0.05$ and $1.69 \pm 0.04 \mathrm{mmol} / \mathrm{l}$ $(59.3 \pm 1.9$ and $65.4+1.5 \mathrm{mg} / 100 \mathrm{ml})$, which yielded a significant difference $(P<0.05)$. The mean age in each group was $53.0 \pm 1.4$ years

TABLE I-Mean ( $\pm S E$ of mean) age, serum total cholesterol concentrations, and serum HDL cholesterol concentrations in male and female controls and patients with juvenile-onset diabetes

\begin{tabular}{|c|c|c|c|c|}
\hline & $\begin{array}{l}\text { No } \\
\text { in } \\
\text { group }\end{array}$ & $\begin{array}{l}\text { Age } \\
\text { in } \\
\text { years }\end{array}$ & $\begin{array}{c}\text { Total } \\
\text { cholesterol } \\
(\mathrm{mmol} / \mathrm{l})\end{array}$ & $\begin{array}{l}\text { HDL } \\
\text { cholesterol } \\
(\mathrm{mmol} / \mathrm{l})\end{array}$ \\
\hline \multicolumn{5}{|c|}{ Males } \\
\hline $\begin{array}{l}\text { Controls } \\
\text { Diabetics } \\
\text { P value }\end{array}$ & $\begin{array}{l}91 \\
45\end{array}$ & $\begin{array}{c}41 \cdot 2 \pm 1 \cdot 6 \\
43 \cdot 3 \pm 2 \cdot 2 \\
\mathrm{NS}\end{array}$ & $\begin{array}{c}5 \cdot 43 \pm 0 \cdot 10 \\
5.99 \pm 0 \cdot 22 \\
<0.001\end{array}$ & $\begin{array}{c}1.40 \pm 0.03 \\
1.51 \pm 0.05 \\
<0.02\end{array}$ \\
\hline \multicolumn{5}{|c|}{ Females } \\
\hline $\begin{array}{l}\text { Controls } \\
\text { Diabetics } \\
\text { P value }\end{array}$ & $\begin{array}{l}86 \\
49\end{array}$ & $\begin{array}{c}43 \cdot 5 \pm 1 \cdot 5 \\
45 \cdot 3 \pm 2 \cdot 3 \\
\mathrm{NS}\end{array}$ & $\begin{array}{c}6 \cdot 01 \pm 0.11 \\
5 \cdot 74 \pm 0.21 \\
\mathrm{NS}\end{array}$ & $\begin{array}{c}1.69 \pm 0.04 \\
1.63 \pm 0.08 \\
\mathrm{NS}\end{array}$ \\
\hline
\end{tabular}

NS $=$ Not significant (comparisons made with Student's $t$ test for unpaired

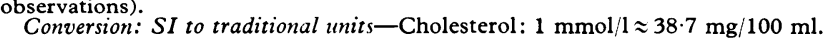

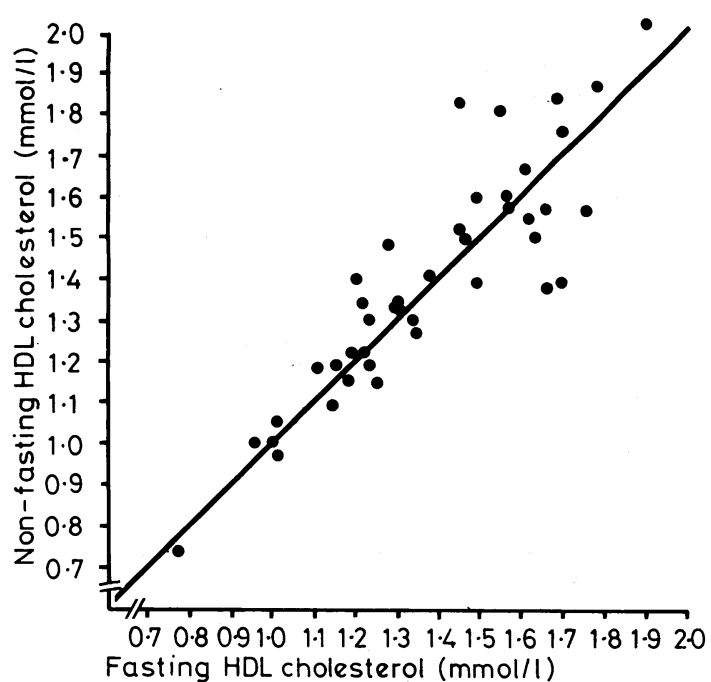

FIG 1-Relation between fasting and non-fasting HDL cholesterol concentrations in 40 subjects.

Conversion: SI to traditional units-Cholesterol: $1 \mathrm{mmol} / 1$ $\approx 38.7 \mathrm{mg} / 100 \mathrm{ml}$.

in the male diabetics; $41.2 \pm 1.6$ in the male controls; $52 \cdot 7 \pm 1.9$ in the female diabetics; and 43.51 .5 years in the female controls. The mean duration of disease was $17 \cdot 7$ years (range one to 46 years) in patients with juvenile-onset diabetes and 5.3 years (range six months to 27 years) in those with maturity-onset diabetes.

Table I compares the patients with juvenile-onset diabetes and the controls according to sex. The ages were comparable, and there was no significant difference in either serum total cholesterol or serum HDL cholesterol concentration between the female patients and female controls. Both of these cholesterol concentrations were significantly higher in the male diabetics than the male controls.

Table II includes only those patients and controls aged over 40 and divides the patients by sex and type of diabetes (juvenile-onset, maturity-onset). Serum total cholesterol concentration was not significantly different within the three groups of female subjects. Serum HDL cholesterol concentration was significantly lower in the female patients with maturity-onset diabetes than in the female controls $(P<0.025)$ and female patients with juvenile-onset diabetes $(\mathbf{P}<0.01)$. Similarly, male patients with maturity-onset diabetes had significantly lower concentrations of HDL cholesterol than either those with juvenile-onset diabetes $(P<0.05)$ or the male controls $(P<0.001)$. Serum total cholesterol concentrations in patients with maturity-onset diabetes did not differ significantly from those in patients with juvenile-onset diabetes and controls.

Serum HDL cholesterol was related to the mode of treatment in patients with maturity-onset diabetes. The mean HDL cholesterol concentration was $1.39 \pm 0.04 \mathrm{mmol} / 1(53.8 \pm 1.5 \mathrm{mg} / 100 \mathrm{ml})$ in 62 patients on a restricted diet and $1.24 \pm 0.06 \mathrm{mmol} / 1(48.0 \pm 2.3 \mathrm{mg}$ $100 \mathrm{ml})$ in 36 patients receiving sulphonylureas by mouth $(\mathrm{P}<0.05)$. Analysing the sexes separately showed that the concentrations were $1 \cdot 37 \pm 0.05 \mathrm{mmol} / \mathrm{l}(53.1+1.9 \mathrm{mg} / 100 \mathrm{ml})$ in the women in the "diet" group and $1.46 \pm 0.01 \mathrm{mmol} / 1(56.5 \pm 0.4 \mathrm{mg} / 100 \mathrm{ml})$ in those receiving

TABLE II-Mean ( $\pm S E$ of mean) age, serum total cholesterol concentration, and serum HDL cholesterol concentration in patients with maturity-onset diabetes compared with those in controls and patients with juvenile-onset diabetes aged over 40 , according to sex

\begin{tabular}{|c|c|c|c|c|c|c|c|c|}
\hline & \multicolumn{4}{|c|}{ Males } & \multicolumn{4}{|c|}{ Females } \\
\hline & $\begin{array}{c}\text { No } \\
\text { in } \\
\text { group }\end{array}$ & $\begin{array}{c}\text { Age } \\
\text { in } \\
\text { years }\end{array}$ & $\begin{array}{c}\text { Total } \\
\text { cholesterol } \\
(\mathrm{mmol} / \mathrm{l})\end{array}$ & $\begin{array}{c}\text { HDL } \\
\text { cholesterol } \\
(\mathrm{mmol} / \mathrm{l})\end{array}$ & $\begin{array}{l}\text { No } \\
\text { in } \\
\text { group }\end{array}$ & $\begin{array}{c}\text { Age } \\
\text { in } \\
\text { years }\end{array}$ & $\begin{array}{c}\text { Total } \\
\text { cholesterol } \\
(\mathrm{mmol} / \mathrm{l})\end{array}$ & $\begin{array}{c}\text { HDL } \\
\text { cholesterol } \\
(\mathrm{mmol} / \mathrm{l})\end{array}$ \\
\hline $\begin{array}{l}\text { Controls } \\
\text { P value* } \\
\text { Patients with maturity-onset diabetes } \\
\text { P value* } \\
\text { Patients with juvenile-onset diabetes }\end{array}$ & $\begin{array}{l}42 \\
61 \\
26\end{array}$ & $\begin{array}{l}56 \cdot 2 \pm 0 \cdot 13 \\
<0 \cdot 001 \\
60 \cdot 1 \pm 0 \cdot 9 \\
<0 \cdot 001 \\
53 \cdot 7 \pm 1 \cdot 3\end{array}$ & $\begin{array}{c}5 \cdot 73 \pm 0 \cdot 12 \\
\mathrm{NS} \\
5 \cdot 83 \pm 0 \cdot 16 \\
\mathrm{NS} \\
6 \cdot 26 \pm 0 \cdot 33 \dagger\end{array}$ & $\begin{array}{l}1.43 \pm 0.06 \\
<0.025 \\
1.30 \pm 0.04 \\
<0.01 \\
1.51 \pm 0.08\end{array}$ & $\begin{array}{l}49 \\
37 \\
31\end{array}$ & $\begin{array}{l}53 \cdot 1 \pm 1 \cdot 2 \\
<0 \cdot 001 \\
62 \cdot 4 \pm 1 \cdot 4 \\
<0 \cdot 001 \\
55 \cdot 8 \pm 1 \cdot 7\end{array}$ & $\begin{array}{l}6 \cdot 42 \pm 0 \cdot 12 \\
\mathrm{NS} \\
6 \cdot 56 \pm 0 \cdot 21 \\
\mathrm{NS} \\
6 \cdot 16 \pm 0 \cdot 26\end{array}$ & $\begin{array}{l}1 \cdot 72 \pm 0.06 \\
<0 \cdot 001 \\
1 \cdot 41 \pm 0.06 \\
<0 \cdot 05 \\
1.66 \pm 0 \cdot 10\end{array}$ \\
\hline
\end{tabular}

NS $=$ Not significant (comparison made with Student's $t$ test for unpaired observations).
*P values are for differences in mean concentrations between patients with maturity-onset diabetes and controls, and between patients with maturity-onset and juvenile-onset *P values are
diabetes.

$\uparrow \mathrm{P}<0.05$-significance of difference in mean cholesterol concentration between male controls and male patients with juvenile-onset diabetes; all other differences between controls and patients with juvenile-onset diabetes were not significant. 
sulphonylureas (difference not significant). The mean concentration in the men treated with sulphonylurea drugs was $1.09 \pm 0.05 \mathrm{mmol} / 1$ $(42.2 \pm 1.9 \mathrm{mg} / 100 \mathrm{ml})$, while that in the men in the "diet" group was $1.41 \pm 0.05 \mathrm{mmol} / 1(54.6-1.9 \mathrm{mg} / 100 \mathrm{ml})$. Thirty-six of the 98 patients with maturity-onset diabetes were receiving an oral hypoglycaemic agent; the mean duration of diabetes in this group was 10.0 years. The other 62 patients had been treated by dietary management for 2.9 years.

Rank correlation coefficients were determined for HDL cholesterol and fasting triglyceride concentration, fasting serum insulin concentration, and percentage of ideal body weight in the 60 patients with maturity-onset diabetes ( 23 women, $37 \mathrm{men}$ ) who were in the prospective study of dietary control. HDL cholesterol was inversely correlated with triglyceride in the women $(\mathrm{r}=-0.41, \mathrm{P}<0.01)$ and the men $(r=-0.24, P<0.05)$. No correlation was found between HDL cholesterol and either fasting serum insulin concentrations or percentage of ideal body weight in either men or women.

Figure 2 shows the $\mathrm{Hb} \mathrm{A}_{1 \mathrm{C}}$ values in the diabetic patients and controls. In the controls $\mathrm{Hb} \mathrm{A}_{1 \mathrm{C}}$ ranged from about 3\% to $7 \%$; there was no difference between the sexes, but a trend for $\mathrm{Hb} A_{1 C}$ to increase with age was noted. Mean $\mathrm{Hb} \mathrm{A} \mathrm{A}_{1 \mathrm{C}}$ in controls aged 10-19 years was $3.8 \%$ and in those aged $60-69$ years $5.3 \%$, mean values in intervening decades being intermediate. Serum HDL cholesterol concentration was not related to $\mathrm{Hb} A_{1 C}$ values in 55 patients with juvenile-onset diabetes $(r=0.15)$ or in 34 with maturity-onset diabetes $(r=0.04)$.

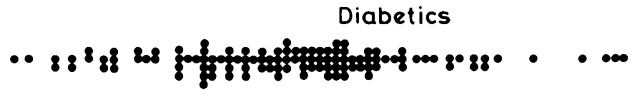

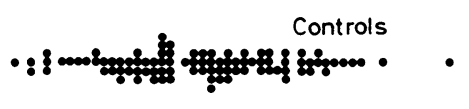

$\begin{array}{lcccccccccc}0_{\text {Haemoglobin } A_{1 C}}^{4}(\%) & 3 & 6 & 7 & 8 & 9 & 10 & 11 & 12\end{array}$

FIG 2- $\mathrm{Hb} \mathrm{A}_{1 \mathrm{C}}$ values in controls and diabetic patients.

\section{Discussion}

Diabetes mellitus is a common metabolic disorder affecting carbohydrate and lipid metabolism. Serum total cholesterol concentrations have been measured reliably for almost 50 years, but their importance in diabetes mellitus is not precisely defined. The heterogeneity of diabetic patients (juvenile- or maturityonset; treatment by diet, oral agents, or insulin; and metabolic differences between the sexes) may account for some of this lack of definition. In 1935 Mann and Peters found no association between serum total cholesterol concentrations and arteriosclerosis in diabetic patients, ${ }^{12}$ but later studies found higher total cholesterol concentrations in diabetics with vascular complications..$^{13-15}$ A current view regarding serum total cholesterol concentrations and diabetes mellitus was summarised by the Joint Working Party on Prevention of Coronary Heart Disease" : "There is much evidence of the increased frequency of hyperlipidaemia in the clinical diabetic, often associated with obesity and usually manifest by raised triglyceride levels and occasionally with hypercholesterolaemia."

Estimating cholesterol by means of high- and low-density fractions has introduced a further variable. Concentrations of HDL cholesterol, postulated to protect against atheroma, were low in female diabetics in the Framingham study ${ }^{4}$; these patients were also obese and had a high incidence of coronary heart disease. Reckless $e t$ al $^{17}$ suggested that although vascular disease in diabetes was related to low concentrations of HDL cholesterol, a stronger association existed with raised LDL cholesterol concentrations.

In the present study we did not try to correlate HDL cholesterol with vascular disease but tried to establish whether HDL cholesterol concentrations were abnormal in diabetics compared with non-diabetic controls. We found that women with juvenile-onset diabetes had serum total cholesterol and HDL cholesterol concentrations similar to those in controls, whereas both these concentrations were higher in the men with juvenileonset diabetes than controls. The ratio of HDL cholesterol to total cholesterol, however, did not differ between the male diabetics and controls, suggesting that the raised HDL cholesterol concentrations in the diabetics were related to the higher total cholesterol concentrations. This positive relation of HDL cholesterol to total cholesterol has been noted previously. ${ }^{1}$

In the Framingham population serum HDL cholesterol was higher in premenopausal women than in men or postmenopausal women. In the South Carolina diabetic study ${ }^{5}$ HDL cholesterol did not vary with age in non-diabetic men. A study of a normal adult American population ${ }^{18}$ (the Modesto study), which included lipoprotein analysis of 160 normal subjects randomly selected to include 20 of each sex for each age decade within 27-66 years, found a progressive increase in HDL concentration from one decade to the next in both sexes.

In order to minimise any possible age effect in the patients with maturity-onset diabetes we compared them with patients with juvenile-onset diabetes and non-diabetic controls aged over 40 (table II). We believe that our most important findings concern these patients with maturity-onset diabetes. Although serum total cholesterol concentrations were similar in the three groups (controls, maturity-onset, juvenile-onset), the mean serum HDL cholesterol concentration was significantly lower in the patients with maturity-onset diabetes than in those with juvenile-onset diabetes and the controls. This is particularly interesting in view of the known association between coronary heart disease and maturity-onset diabetes, which has macroangiopathy rather than microangiopathy as an end complication. Schonfield et al ${ }^{19}$ similarly found low HDL cholesterol concentrations in normolipaemic diabetic patients, most of whom had maturity-onset diabetes; and Baker et $a l^{20}$ found a higher $\beta$-lipoprotein to $\alpha$-lipoprotein ratio in diabetics than controls, particularly in those aged over 50. Moreover, though in the Framingham study ${ }^{3}$ the type of diabetes was not clearly defined, only $20 \%$ of the patients were receiving insulin, suggesting a preponderance of those with maturity-onset diabetes. Support for an abnormality of HDL affecting specifically patients with maturity-onset diabetes is not found in the detailed Westminster Hospital study. ${ }^{21}$ While treated and untreated diabetics had similar cholesterol concentrations to age-matched controls, the diabetics had raised $\beta$-lipoprotein and lower $\alpha$-lipoprotein concentrations; but this finding concerned all age groups within the diabetic population.

In the present study the lowest HDL cholesterol concentrations occurred in male diabetics treated with sulphonylureas. This need not imply a cause-and-effect relation. In retrospective studies associations between vascular disease and sulphonylurea treatment might indicate a gradient within the group with maturity-onset diabetes-that is, that the more severe the diabetes the greater the likelihood of the patient needing sulphonylurea treatment-and these more severely affected patients have an inherently greater liability to vascular disease. ${ }^{22}$ In the present study, however, we were unable to show such a gradient with regard to HDL cholesterol and insulin concentrations.

We found a negative correlation between HDL cholesterol and fasting serum triglyceride concentrations in 60 patients, who were participating in a study of intensive dietary management of maturity-onset diabetes. As raised triglyceride concentrations have often been reported in poorly controlled diabetics, our finding of an inverse relation between triglyceride and HDL cholesterol concentrations suggests some association between diabetic control and HDL cholesterol concentrations. $\mathrm{Hb} \mathrm{A}_{1 \mathrm{C}}$ is postulated as an accurate reflection of diabetic control, and our failure to find an association between it and HDL cholesterol suggests the complexity of assessing diabetic control. Our estimations of $\mathrm{Hb} \mathrm{A}_{1 \mathrm{C}}$ in diabetics receiving treatment showed an upper limit of $12 \%$, whereas other workers ${ }^{6} 8$ have studied patients with $\mathrm{Hb} \mathrm{A}_{1 \mathrm{C}}$ values up to $18 \%$, and in this range cholesterol and HDL cholesterol concentrations may be correlated 
with $\mathrm{Hb} \mathrm{A}_{1 \mathrm{C}}$. Patients with very high $\mathrm{Hb} \mathrm{A}_{1 \mathrm{C}}$ values possibly represent a subgroup of the diabetic population, outside the normal criterion of long-term control, during a phase of metabolic decompensation; and they may show features more typical of the lipid disturbances of ketosis than of long-term diabetic control.

Thus our main finding is related not to diabetic control but to the type of diabetes, in that patients with maturity-onset diabetes have abnormally low HDL cholesterol concentrations irrespective of vascular disease and, possibly, of mode of treatment, whereas patients with juvenile-onset diabetes have essentially normal concentrations of HDL cholesterol.

We thank Professor M G Nelson and Mr D W Neill, principal biochemist, for laboratory facilities, and Mrs Mildred Fry and Miss May Weller for their help.

\section{References}

1 Castelli, W P, et al, Circulation, 1977, 55, 767.

2 Miller, G J, and Miller, N W, Lancet, 1975, 1, 16.

3 Gordon, T, et al, Annals of Internal Medicine, 1977, 62, 707.

4 Gordon, T, et al, Annals of Internal Medicine, 1977, 87, 393.
${ }^{5}$ Lopes-Virella, M F L, Stone, P G, and Colwell, J A, Diabetologia, 1977, $13,285$.

6 Calvert, G D, et al, Lancet, 1978, 2, 66.

${ }^{2}$ Koenig, R J, et al, New England fournal of Medicine, 1976, 295, 417.

${ }^{8}$ Gabbay, K H, et al, fournal of Clinical Endocrinology and Metabolism, 1977, 44, 859.

${ }^{9}$ Hadden, D R, et al, British Medical fournal, 1975, 3, 276.

10 Steele, B W, et al, Clinical Chemistry, 1976, 20, 98.

11 Trivelli, L A, Ranney, H M, and Lai, H-T, New England fournal of Medicine, 1971, 284, 353.

12 Man, E B, and Peters, J P, fournal of Clinical Investigation, 1935, 14, 579.

13 Pomeranze, J, and Kunkel, H G, Proceedings of the American Diabetes Association, 1950, 10, 217.

${ }_{14}$ Keiding, N R, et al, Diabetes, 1952, 1, 434.

15 Adlersberg, D, et al, Diabetes, 1956, 5, 116

16 Report of a Joint Working Party of the Royal College of Physicians of London and the British Cardiac Society, fournal of the Royal College of Physicians of London, 1976, 10, 213.

${ }^{17}$ Reckless, J P D, et al, British Medical fournal, 1978, 1, 883.

18 Anderson, D W, et al, Atherosclerosis, 1978, 29, 161.

19 Schonfeld, G, et al, Diabetes, 1974, 23, 827.

${ }^{20}$ Baker, R W R, Joiner, C L, and Trounce, J R, Quarterly fournal of Medicine, 1955, 24, 295.

${ }^{21}$ Billimoria, J D, Isaacs, A J, and Melki, K, Annals of Clinical Biochemistry, $1976,13,315$.

${ }^{22}$ Hadden, D R, et al, Practitioner, 1973, 210, 655.

(Accepted 31 August 1978)

\section{SIDE EFFECTS OF DRUGS}

\section{Ritodrine-induced acidosis in pregnancy}

Beta-sympathomimetic agents such as salbutamol, terbutaline, and ritodrine ${ }^{1}$ are commonly used to prevent premature delivery but may have metabolic side effects, ${ }^{2}{ }^{3}$ particularly in the case of salbutamol. ${ }^{4}$ Enhanced lipolysis and glycolysis result in raised blood glucose, fatty acid, and lactate concentrations and a fall in serum bicarbonate. ${ }^{5}$ Severe metabolic acidosis, however, has been described only in pregnancy complicated by diabetes. ${ }^{6}$ We report a case of decompensated acidosis that occurred during an infusion of ritodrine.

\section{Case report}

An 18-year-old woman in the 32 nd week of pregnancy was admitted to the department of obstetrics having been in labour for about two hours. The cervix admitted one finger and the membranes were intact. Ritodrine, diluted in $5 \%$ dextrose in water, was infused by a pump at $100 \mu \mathrm{g} / \mathrm{min}$ to delay delivery. Hydrocortisone succinate $1 \mathrm{~g}$ four times daily was given intravenously to prevent neonatal lung prematurity. Twelve hours after admission abdominal tenderness unrelated to uterine contractions was noted. Fetal heart rate monitoring showed a permanent tachycardia of $170 / \mathrm{min}$ and some late decelerations. The mother also had tachycardia but was otherwise physically normal. Attention was drawn to a serum bicarbonate concentration of $8 \mathrm{mmol}(\mathrm{mEq}) / \mathrm{l}$ with a $10 \mathrm{mmol} / \mathrm{l}$ anion gap. Qualitative test for ketonuria was negative. Blood glucose concentration was $8.8 \mathrm{mmol} / 1(159 \mathrm{mg} / 100 \mathrm{ml})$ and $\mathrm{pH} 7 \cdot 25$. Ritodrine infusion was slowed to $30 \mu \mathrm{g} / \mathrm{min}$ and sodium bicarbonate ( $40 \mathrm{mmol} /$ hour) given. Three hours later the serum lactate concentration was $7 \mathrm{mmol} / 1(63 \mathrm{mg} / 100 \mathrm{ml})$ and the anion gap $8 \mathrm{mmol} / 1$. Ritodrine was stopped, and within three hours the lactate and bicarbonate concentrations were $2.7 \mathrm{mmol} / 1(24.3 \mathrm{mg} / 100 \mathrm{ml})$ and $20 \mathrm{mmol} / 1$ respectively. Delivery occurred 24 hours after admission; mother and child did well.

\section{Comment}

Although we cannot exclude the possibility of mild gestational daibetes in this case, normal fasting and postprandial blood glucose concentrations the day after delivery strongly suggest that the patient had a normal glucose tolerance. We therefore conclude that ritodrine, associated with corticosteroids, induced transient severe acidosis with predominant hyperlactacidaemia.

Blood electrolyte and glucose concentrations should be carefully monitored in non-diabetic patients given ritodrine for premature labour to detect potentially harmful metabolic acidosis.

${ }^{1}$ Wesselius-de Casparis, A, et al, British Medical fournal, 1971, 3, 144.

2 Thomas, D J B, Dove, A F, and Alberti, K G M M, British fournal of Obstetrics and Gynaecology, 1977, 84, 497.

${ }^{3}$ Spellacy, W N, et al, American fournal of Obstetrics and Gynecology, 1978, 131, 637

4. Chapman, M G, British Medical Fournal, 1977, 1, 639.

${ }^{5}$ Lipshitz, J, and Vinik, A I, American fournal of Obstetrics and Gynecology, 1978, 130, 761 .

${ }^{6}$ Leslie, D, and Coats, P M, British Medical fournal, 1977, 2, 768.

(Accepted 27 September 1978)

Departments of Medicine and Gynaecology, Hôpital Universitaire Saint-Pierre, Rue Haute 322, 1000 Brussels, Belgium

D DESIR, MD, assistant in medicine

A VAN COEVORDEN, $M D$, assistant in medicine

C KIRKPATRICK, MD, fellow of the Lekime-Ropsy Foundation A CAUFRIEZ, $M D$, assistant in gynaecology

\section{Reversible oliguric renal failure associated with ibuprofen treatment}

Nephrotoxicity has been associated with non-steroidal anti-inflammatory agents such as phenylbutazone, oxyphenbutazone, and aspirin. ${ }^{1}$ It has not been reported after use of ibuprofen, although similar propionic-acid derivatives-namely, fenoprofen and naproxen-have been associated with renal papillary necrosis. ${ }^{2}$ We report here a case of reversible oliguric renal failure, which occurred in a patient with osteoarthritis treated with normal doses of ibuprofen.

\section{Case report}

A 65-year-old man was admitted to this hospital with acute left-sided weakness. His medical history included atherosclerotic and hypertensive cardiovascular diseases treated with frusemide, spironolactone, and digoxin; 